\title{
IMPLEMENTASI SUPERVISI KEPALA SEKOLAH PADA KOMPETENSI PEDAGOGIK GURU
}

\author{
Ike Nilawati Rohaenah | Sahudi \\ Muhibbin Syah | Mohamad Erihadiana \\ Pascasarjana UIN Sunan Gunung Djati Bandung \\ nilawatirohaenahike@gmail.com
}

\begin{abstract}
The problems faced by teachers tend to carry out learning very rigidly and even conventional. This can be seen from the learning design in the form of RPP and the results of the observation of Teaching and Learning Activities in the initial study of teacher pegagogical supervision that the researcher did, showing the need for coaching by the principal of the teacher's ability to manage ideal learning in the classroom as an effort to boost the quality of learning. The research objective was to analyze and describe: 1) Planning the principal's supervision program in improving teacher pedagogical competence. 2) Process supervision of school principals in improving teacher pedagogical competence. 3) Follow-up supervision of the principal in improving teacher pedagogical competence. The research method used is descriptive. The informants in this study included the principal and teachers. The results of the study make a clinical model of the implementation of Principal Supervision in improving Teacher Pedagogical Competence. The teacher can compile a Learning Implementation Plan (RPP). Teaching and learning activities are more fun, teacher pedagogical competence increasing, teachers are included in seminars and workshops. Improving the quality of education with increased graduate results. The research activities will be carried out from January 2020 to June 2020 at the Islamic Boarding School MTs Darunnadawah and MTs Al Ahliyah Karawang, West Java.
\end{abstract}

Keywords: Clinical supervision; teacher; pedagogical competence 


\section{Abstract}

Masalah yang dihadapi guru cenderung melaksanakan pembelajaran dengan kaku bahkan konvensional. Hal ini tampak dari rancangan pembelajaran dalam bentuk RPP dan hasil observasi Kegiatan Belajar Mengajar pada studi awal supervisi pegagogik guru yang peneliti lakukan, menunjukan masih perlunya pembinaan oleh kepala sekolah terhadap kemampuan guru dalam mengelola pembelajaran yang ideal di kelas sebagai upaya mendongkrak kualitas pembelajaran. Tujuan penelitian adalah untuk menganalisis dan mendeskripsikan:1) Perencanaan program supervisi kepala sekolah dalam meningkatkan kompetensi pedagogik guru. 2) Proses supervisi kepala sekolah dalam meningkatkan kompetensi pedagogik guru. 3) Tindak lanjut supervisi kepala sekolah dalam meningkatkan kompetensi pedagogik guru. Metode penelitian yang digunakan adalah deskriptif. Informan pada penelitian ini meliputi kepala sekolah, dan guru. Hasil penelitian membuat model Klinis implementasi Supervisi Kepala Sekolah dalam meningkatkan Kompetensi Pedagogik Guru. Guru dapat menyusun Rencana Pelaksanaan Pembelajaran (RPP). Kegitan belajar mengajar lebih menyenangkan,Kompetensi pedagogik guru meningkat, Guru diikut sertakan seminar dan workshop .Meningkatkan mutu pendidikan dengan nilai hasil lulusan meningkat. Kegiatan penelitian dilaksanakan pada bulan Januari 2020 sampai bulan Juni 2020 di Pondok Pesantren MTs Darunnadawah dan MTs Al Ahliyah Karawang Jawa Barat.

Kata Kunci: supervisi klinis; kompetensi; pedagogik guru 


\section{A. Pendahuluan}

Latar belakang di Pondok Pesantren MTs Darunnadawah dan MTs Al Ahliyah Karawang Jawa Barat terutama dalam kualitas pembelajaran dapat diungkapkan bahwa sebagian guru cenderung melaksanakan pembelajaran dengan kaku bahkan konvensional. Guru belum menyiapkan Rencana Pelaksanaan Pembelajaran (RPP). Masih perlu pembinaan oleh kepala sekolah terhadap kemampuan guru dalam mengelola pembelajaran yang ideal di kelas. Karena belum menggunakan metode mengajar yang berfariatif dalam menggunakan alat-alat pelajaran, belum melaksanakan prosedur dan tehnik evaluasi pengajar, belum pula melaksanakan pendekatan kepada siswa.

Hal ini tampak dari rancangan pembelajaran dalam bentuk RPP dan hasil observasi Kegiatan Belajar Mengajar pada studi awal supervisi yang peneliti lakukan, menunjukan masih perlunya pembinaan oleh kepala sekolah terhadap kemampuan guru dalam mengelola pembelajaran yang ideal di kelas sebagai upaya mendongkrak kualitas pembelajaran.

Penggunaan metode mengajar, menyiapkan alat-alat pelajaran, menggunakan prosedur dan tehnik evaluasi pengajar, melakukan pendekatan kepada siswa. Berdasarkan konteks tersebut diatas, maka rumusan masalah yang akan dibahas dalam artikel ini adalah (1). Pelaksanakan pembelajaran monoton bahkan konvensional sehingga kegiatan belajar mengajar kaku. (2). Guru belum menyiapkan Perencanaan Pelaksanaan Pembelajaran (RPP). (3). Guru masih perlu pembinaan kepala sekolah terhadap kemampuan guru dalam mengelola pembelajaran yang ideal di kelas. (4). Guru belum menggunakan metode mengajar berfariatif. 5. Belum menggunakan alat-alat pelajaran. (6). Guru belum melaksanakan prosedur dan tehnik evaluasi pengajar. (7). Guru belum melaksanakan pendekatan kepada siswa. 


\section{B. Metode}

Tujuan penelitian adalah untuk mengetahui pelaksanaan, supervisi klinis dan kompetensi pedagogik guru dan hasil ilmplementasi supervisi kepala sekolah dalam kompetensi pedagogik guru di Pondok Pesantren MTs Darunnadawah dan MTs al-Ahliyah Karawang Jawa Barat.

Metode penelitian yang digunakan adalah kualitatif dengan pendekatan deskriptif lapangan. Alur Penelitian (Flow Chart). Metoda penelitian ini berguna sebagai acuan dalam melakukan penelitian sehingga penelitian dapat berjalan secara sistematis, tujuan tercapai dan sesuai dengan waktu yang ditentukan sebelumnya. Berisi alur penelitian, penjelasan masing masing tahapan dalam alur penelitian, dan jadwal pengerjaan penelitian.

\section{Pembahasan}

Dalam Undang-Undang Republik Indonesia Nomor 14 Tahun 2005 tentang Guru dan Dosen Bab I Ketentuan Umum pasal 1 poin 10, dinyatakan bahwa: "kompetensi adalah seperangkat pengetahuan, keterampilan, dan perilaku yang harus dimiliki, dihayati, dan dikuasai oleh guru atau dosen dalam melaksanakan tugas keprofesionalan."

Beberapa pendapat para sarjana, antara lain:

Pertama, E Mulyasa juga menyatakan: "Kompetensi guru merupakan perpaduan antara kemampuan personal, keilmuan, teknologi, sosial dan spiritual yang secara kaffah membentuk kompetensi standar profesi guru, yang mencakup penguasaan materi, pemahaman terhadap peserta didik, pembelajaran yang mendidik, pengemabngan pribadi dan profesionalisme."

Kedua, B. Suryobroto menyatakan bahwa "Adanya pelaksanaan supervisi oleh kepala sekolah kepada guru yang terus-menerus terhadap berbagai aspek akademik dan administratif dan pemanfaatan hasilnya untuk penyempurnaan atau perbaikan mutu. ${ }^{3}$

${ }^{1}$ Undang-Undang Republik Indonesia Nomor 14 Tahun 2005 Tentang Guru dan Dosen.

${ }^{2}$ E Mulyasa, Standar Kompetensi dan Sertifikasi Guru (Bandung: Remaja Rosda Karya, 2008), 26.

${ }^{3}$ E Mulyasa, Menjadi Kepala Sekolah Profesional (Bandung: PT Remaja Rosdakarya, 2007), 98-99. 
Ketiga, E. Mulyasa menyatakan dalam melakukan fungsinya sebagai educator, "kepala madrasah harus memiliki strategi yang tepat untuk meningkatkan kompetensi pedagogik tenaga kependidikan di madrasahya. Menciptakan iklim sekolah yang kondusif, memberikan nasehat kepada warga sekolah, memberikan dorongan kepada seluruh tenaga kependidikan, serta melaksanakan model pembelajaran yang menarik, seperti team teaching, moving class, dan mengadakan akselerasi (acceleration) bagi peserta didik yang cerdas di atas normal ${ }^{4}$

Model supervisi yang dikembangkan adalah konsep supervisi klinis. Tujuan supervisi klinis adalah membantu guru mengembangkan dan meningkatkan profesionalitasnya melalui perencanaan bersama (guru dan supervisor), observasi dan umpan balik. Konsep yang dikembangkan diadopsi dari Acheson \& Gall, yaitu mengembangkan lima tahap supervisi klinis yaitu "The CSM cycle includes pre-conference, observation and data collection, data analysis, post-conference, and refection stages.

Berdasarkan hasil studi pendahuluan, secara empiris ditemukan hal-hal sebagai berikut. Pertama, kepala sekolah, guru bahkan supervisor belum memahami secara utuh apa yang dimaksud dengan supervisi klinis. Kedua, kegiatan supervisi masih dipersepsikan sebagai program kepala sekolah dan program pengawas. Sehingga guru bersifat pasif menunggu kapan kepala sekolah atau pengawas sempat mensu-pervisi guru tersebut. Ketiga, membina guru merupakan salah satu tugas dari supervisor, dan menjadi program sekolah, bila kondisi demikian nampaknya guru pasif untuk meningkatkan ke-mampuan mengajar. Keempat, pada kondisi nyata guru harus disupervisi dan banyak jumlahnya, sedangkan waktu terbatas, maka melalui bantuan informasi dan teknologi dapat dijadikan salah satu strategi untuk membina guru dengan mensiasati strategi waktu tanpa harus bertemu dalam waktu nyata (real time) pada setiap tahap supervisi klinis, karena dengan menggunakan media informasi dan teknologi (IT) komunikasi akan tetap berlangsung tanpa kendala waktu harus bertemu secara berkala dengan frekuensi yang sering untuk meningkatan kemampuan belajar siswa dan kemampuan mengajar guru, dengan beberapa tahapan.

${ }^{4}$ B.Suryobroto, Manajemen Pendidikan di Sekolah, (Jakarta: PT Rineka Cipta, 2010), 198. 
Menurut Glickman menjelaskan lima langkah supervisi klinis, yaitu: (1) Pra konferensi dengan guru; (2) Observasi kelas; (3) Analisis interpretasi observasi dan menetapkan pendekatan konverensi; (4) Pertemuan yang dilakukan setelah melakukan observasi; (5) Melakukan kritik empat langkah sebelumnya.

Pelaksanaan supervisi pendidikan yang dilakukan oleh kepala madrasah di MTs menggunakan teknik tertentu, selain teknik, juga menggunakan model supervisi Klinis. Teknik yang digunakan kepala madrasah adalah teknik individual yaitu dengan cara kunjungan kelas, observasi kelas dan wawancara perseorangan.

Adapun model supervisi yang diimplementasikan adalah model supervisi klinis yang memfokuskan pada peningkatan mengajar. Dari data tersebut, berarti pada saat pelaksanaan supervisi yang dilakukan oleh kepala madrasah juga mempengaruhi proses pembelajaran yang berlangsung. Dalam wawancara tersebut sudah dijelaskan bahwa kepala madrasah dalam melaksanakan supervisi menggunakan teknik individual dan menggunakan model supervisi klinis yang memfokuskan pada peningkatan kompetensi pedagogik guru dalam proses belajar mengajar.

Selain model supervisi klinis, juga menggunakan supervisi dilakukan secara berencana dan kontinyu. Dan guru tersebut mendukung kegiatan supervisi pendidikan yang dilakukan oleh kepala MTs. Guru tersebut sangat yakin bahwa apa yang telah dilakukan oleh kepala MTs tersebut akan membawa dampak yang baik bagi semua pihak di lembaga tersebut. Dari semua hasil wawancara di atas, peneliti dapat menyimpulkan bahwa pelaksanaan supervisi pendidikan yang dilakukan oleh kepala MTs dilaksanakan dengan teknik individual, model supervisi klinis.

Faktor penghambat yang utama adalah kurangnya waktu. Selain itu juga penghambat yang berasal langsung dari para guru dan kendala yang dihadapi guru Pendidikan Agama Islam (PAI) adalah kemampuan siswa yang berbeda memerlukan waktu tertentu untuk bimbingan khusus agar hasil akhir dari pembelajar dan pemahaman siswa sama. 
Dari semua paparan hasil wawancara di atas, intinya adalah waktu pelaksanaan supervisi masih kurang karena adanya kendala tersebut yang seharusnya tiap semester satu kali supervisi kunjungan kelas terkadang tidak bisa terlaksana sehingga belum mendapatkan kesempatan waktu itu.

Selain faktor waktu yang dirasa menghambat jalannya supervisi adalah sikap dari guru itu sendiri yag kurang begitu menerima adanya kegiatan supervisi tersebut.

Guru yang seperti itu sulit untuk diajak melakukan perubahan, guru yang masih kurang mempersiapkan misal RPP ataupun yang lainnya. Dan kadang untuk mengakui kekurangannya saja juga sulit karena merasa bahwa apa yang telah dilakukannya selama ini sudah benar. Perbaikan atau peningkatan mutu pengajaran di sekolah berkaitan erat dengan keefektifan layanan supervisi. Karena itu, sudah seharusnya pula para supervisor mendorong para guru agar berupaya dalam melakukan peningkatan kemampuan kompetensi pedagogik guru.

Observasi kelas adalah salah satu wahana yang dapat digunakan untuk mendapatkan perubahan atau perbaikan unjuk kerja mengajar guru. Karena pula, supervisor diharapkan dapat menggiring perhatian guru dalam wawancara supervisi terhadap temuan spesifik dari observasi kelas, dengan harapan minat dan kemauan guru dibangkitkan untuk melakukan perubahan atau perbaikan unjuk kerja mengajarnya.

Kepala MTs mempunyai solusinya yaitu dengan menunjuk beberapa orang yang dipercaya mampu untuk melaksanakan supervisi terhadap guru-guru. Selain itu, untuk mempercepat proses supervisi, kepala MTs juga mempunyai form penilaian untuk menilai guru yang sedang disupervisi.

Dari paparan hasil wawancara tersebut bahwasanya evaluasi supervisi sangat diperlukan bagi setiap guru yang disupervisi karena pada proses ini guru mengetahui kelebihan dan kekurangannnya dalam melaksanakan kegiatan pembelajaran selain itu dari pihak supervisor sendiri juga akan tahu hal yang perlu diperbaiki, selanjutnya dari kegiatan tersebut supervisor dapat memberikan masukan kepda pihak yang disupervisi atau solusi ketika ada kesulitan dalam kegiatan pembelajaran. 
Hasil wawancara tersebut, dapat disimpulkan bahwa pelaksanaan supervisi tidak hanya dilakukan oleh kepala madrasah, tetapi juga dengan di bantu oleh waka bahkan guru yang sudah dibimbing untuk menjadi supervisor.

Dibagian awal tulisan ini dijelaskan bahwa yang bertanggung jawab atas pelaksanaan supervisi adalah pengawas dan kepala sekolah. Isi kegiatan supervisi dimaksud meliputi antara lain mengadakan pengamatan kelas. Jika pengawas mempunyai kesulitan dalam mengadakan pengamatan kelas karena keterbatasan latar belakang bidang studi, demikian juga halnya kepala madrasah, dapat dibantu oleh guru atau personel lain.

Namun demikian karena kepala madrasah diibaratkan sebagai pemilik sekolah tentu yang bersangkutan sangat faham tentang seluk beluk kehidupan sekolah sehari-hari. Dalam menunjang pelaksanaan seperti disebutkan dalam deskripsi tugas kepala madrasah sebagai supervisor, setiap hari beliau dapat dengan langsung pula memberikan pembinaan untuk peningkatan. Selain hal tersebut, kepala madrasah juga memanggil guru untuk memberikan RPP dan mewawancarai apakah sudah sesuai dengan RPP ketika mengajar atau menggunakan form untuk mengetahui apakah tiap-tiap form sudah terlaksana ketika proses KBM. Sehingga hal tersebut dapat dijadikan solusi untuk mengatasi hambatan yang terjadi. 


\section{Analisis Data}

Dalam melaksanakan suatu kegiatan tentunya penelitian supervisi kepala sekolah, dari hasil wawancara yang telah peneliti lakukan terdapat hal perlu dianalisis. Analisis data ini melibatkan hal yang penting dan penentuan apa yang dilaporkan. Hal yang perlu diuraikan tersebut meliputi hambatan dan solusi untuk mengatasi hambatan dalam tema penelitian yang sudah peroleh setelah pengumpulan data. Sebagaimana yang telah di peroleh berikut:

Proses pengumpulan data penelitian, peniliti mendapatkan data melalui observasi, dokumentasi dengan subyek yang diteliti, wawancara dalam kegiatan ini dilaksanakan pada pagi atau siang hari di Pondok Pesantren MTs Darunnadawah dan MTs alAhliyah Karawang Jawa Barat.

Untuk observasi peneliti melakukan di lingkungan madrasah terkait pelaksanaan untuk penelitian. Sedangkan wawancara itu dilakukan terhadap kepala madrasah, waka kurikulum dan guru yang bersangkutan dalam kegiatan wawancara tidak hanya dilakukan satu kali selesai akan tetapi memerlukan waktu beberapa kali secara bergantian supaya hasil dari wawancara yang di dapatkan lebih maksimal. Langkah berikutnya adalah dokumentasi, hal dilakukan ketika penelitian wawancara dengan kepala sekolah, waka kurikulum dan guru yang bersangkutan bahkan apabila terdapat suatu hal perlu untuk dijadikan bahan penilitian seperti jadwal ataupun data-data yang terkait dengan peneliatian supervisi.

Data yang didapat peneliti dalam kegiatan tersebut yang yaitu:

1) Pelaksanaan supervise

Supervisi dilaksanakan di pada tiap semester oleh supervisor, untuk supervisor tersebut kepala sekolah memberikan bimbingan terlebih dahulu kepada guru yang diberi kewenangan mensupervisi guru lainnya. Tujuan dari pelaksanaan supervisi yang ingin dicapai yaitu meningkatkan kompetensi pedagogik para guru. 
Tujuan supervisi dapat dibedakan menjadi dua, yaitu tujuan umum dan tujuan khusus: (a). Tujuan umum supervisi menunjuk pada makna supervisi yaitu memberikan bantuan teknis dan pembimbingan kepada staf sekolah yang lain. Selanjutnya tujuan umum tersebut dijabarkan menjadi tuan tujuan khusus supervisi, agar lebih jelas arah untuk mencapainya, karena tujuan khusus tersebut sudah menunjukan aspek-aspek supervisi. (b). Tujuan khusus supervisi diarahkan pada kinerja komponenkomponen supervisi antara lain: Supervisi klinis dan kompetensi pedagogik, lingkungan dan Situasi umum Selanjutnya setelah pelaksanaan kegiatan perlu adanya evaluasi.

Evaluasi terhadap guru yang disupervisi dimaksudkan untuk mengetahui apakah terdapat perbedaan kemampuan, keterampilan, kepuasan, dan kompetensi pedagogik guru sebelum dan sesudah mendapatkan supervisi. Perubahan dan atau peningkatan demikian perlu diketahuai, agar dapat diketahui tingkat keberhasilan supervisi. Akan tetapi supervisor juga memiliki keterbatasan kemampuan untuk mengetahui segalagalanya, tetapi telah di ketahui bahwa supervisor memiliki kemampuan dan pengetahuan dalam memajukan pembelajaran.

Supervisor tidaklah dapat memahami beberapa yang dapat memungkinkan kita berfikir, merencanakan dan bekerjasama dengan para guru. Dan pelaksanaan supervisi di diadakan dua kali untuk tiap tahun atau satu kali dalam satu semester dan supervisor dari guru yang sudah di tunjuk dan di bimbing kepala sekolah untuk melaksanakan tugas tersebut. Sasaran atau objek dari tiap-tiap jenis supervisi adalah sesuai dengan nama dan lingkup kajiannya.

Supervisi klinis mengutamakan objek pada aspek-aspek yang langsung tertuju pada proses pembelajaran, antara lain yang terjadi di kelas. Supervisi klinis mengarah pada pada hal yang bersifat kondisional dari kegiatan akademik. Supervisi lembaga mengarah pada semua aspek di sekolah Pondok Pesantren MTs Darunnadawah dan MTs al-Ahliyah Karawang Jawa Barat. 


\section{2) Teknik Supervisi}

Dalam wawancara tersebut sudah dijelaskan bahwa kepala madrasah dalam melaksanakan supervisi menggunakan teknik individual dan menggunakan model supervisi klinis yang memfokuskan pada peningkatan kompetensi pedagogik guru dalam proses belajar mengajar. Untuk teknik pelaksanaan supervisi yang digunakan kepala madrasah adalah teknik individual yaitu dengan cara kunjungan kelas, observasi kelas dan wawancara perseorangan. Selain model supervisi klinis, juga menggunakan. Model supervisi klinis dilakukan secara berencana dan kontinyu. Dan guru tersebut mendukung kegiatan supervisi pendidikan yang dilakukan oleh kepala madrasah.

3) Hambatan Pelaksanaan Supervisi

Dari hasil wawancara yang telah peneliti lakukan, dalam kegiatan supervisi di Pondok Pesantren MTs Darunnadawah dan MTs al-Ahliyah Karawang Jawa Barat terdapat berbagai hambatan termasuk kendala waktu, baik kendala waktu yang dialami oleh kepala madrasah atupun supervisor yang lainnya hal itu terjadi karena adanya kegiatan sekolah, kurang adanya persiapan ataupun faktor yang mencul dari masing-masing guru dan untuk mengatasi hambatan tersebut kepala madrasah berusaha untuk tetap memotivasi guru dan mendorong semangat dengan adanya supervisi tersebut.

Dan apabila supervisor tidak bisa mengunjungi pihak yang di supervisi ke tiap kelas maka supervisor atau kepala madrasah bisa menggunakan tindakan lain seperti pengumpulan RPP maupun wawancara terkait pembelajaran dan pelaksanaan supervisi dengan tujuan meningkatkan profesinalisme guru.

4) Solusi Untuk Mengatasi Hambatan Supervisi

Dalam mengatasi hambatan dari pelaksanaan supervisi pendidikan di Pondok Pesantren MTs Darunnadawah dan MTs al-Ahliyah Karawang Jawa Barat, kepala madrasah mempunyai solusinya yaitu dengan menunjuk beberapa orang yang dipercaya mampu untuk melaksanakan supervisi atau guru yang sudah di bimbing untuk menjadi supervisor terhadap guru-guru.

Supervisor juga harus senantiasa menjaga agar dirinya tidak terjebak pada tindakan menilai saja atau bahkan mengadili pihak guru. Perbaikan dan peningkatan mutu pembelajran di sekolah berkaitan erat dengan keefektifan layanan supervisi. Karena itu, supervisor perlu mendorong guru agar berupaya melakukan peningkatan kemampuam personal dan profesionalnya. 
Observasi kelas adalah salah satu hal yang dapat dilakukan untuk mendapatkan perubahan dan perbaikan unjuk kerja mengajar guru. Supervisor diharapkan dapat menggiring perhatian guru dalam kegiatan wawancara supervisi terhadap temuan spesifik di kelas, dengan harapan minat dan kemauan guru dibangkitkan untuk melakukan perubahan atau perbaikan unjuk kerja mengajarnya.

Pada saat demikian, supervisor hendaknya menyampaikan hasil amatannya sedemikian rupa sehingga guru merasa yakin bahwa tampilan pembelajaran yang baru saja beliaulakukan sebagaimana direkam supervisor. Selain itu, untuk mempercepat proses supervisi, kepala madrasah juga mempunyai form penilaian untuk menilai guru yang sedang disupervisi. Hasil penelitian menunjukan:

1) Pelaksanakan pembelajaran agar tidak monoton kegiatan belajar mengajar kaku. Guru Pondok Pesantren MTs Darunnadawah dan MTs Al Ahliyah Karawang Jawa Barat. terlebih dahulu sudah menyiapkan materi yang akan di ajarkan kepada siswa, guru membaca dan mengumpulkan berbagai macam referensi.

2) Guru menyiapkan Perencanaan Pelaksanaan Pembelajaran (RPP) 


\section{E. Penutup}

Pelaksanaan supervisi klinis telah dilaksanakan dengan baik oleh kepala sekolah dan menghasilkan:

Pertama, pelaksanakan pembelajaran belajar-mengajar menyenangkan. Kedua, guru sudah menyiapkan Perencanaan Pelaksanaan Pembelajaran (RPP). Ketiga, guru telah mencapai perkembangan kemampuan dalam mengelola pembelajaran yang ideal di kelas. Keempat, guru sudah menggunakan metode mengajar bervariatif. Kelima, menggunakan alat-alat pelajaran bervariatif. Keenam, guru telah melaksanakan prosedur dan tehnik evaluasi pengajar. Ketujuh, guru telah melaksanakan pendekatan kepada siswa.

Jadi hubungan siswa dengan guru yang positif juga dikaitkan dengan peningkatan mutu pendidikan pada peserta didik. Selain itu hubungan siswa dengan guru mengarahkan pada banyak upaya untuk menghabiskan waktu bersama untuk belajar bersama dan guru dapat membantu siswa atau peserta didik dalam permasalahan yang dihadapi saat proses belajar mengajar. Hubungan kedekatan antara guru dengan siswa juga dapat mendorong dan memotivasi peserta didik dalam proses belajar.

Beberapa cara yang dilakukan guru untuk meningkatkan motivasi belajar siswa misalnya dengan pembelajar yang inovatif menggunakan media sampai interaksi dan kerjasama yang baik. Motivasi juga mendorong timbulnya kelakuan atau suatu perbuatan. Motivasi juga sebagai pengarah maksudnya disini mengarahkan perbuatan kepada pencapaian tujuan yang diinginkan. Selain itu motivasi juga sebagai penggerak maksudnya besar kecilnya motivasi akan menentukan cepat atau lambatnya suatu pekerjaan. 


\section{Daftar Pustaka}

Baltacyi-Goktalay, et al, "Clinical Supervision Model and Uludag Kdm", in International Journal on New Trends in Education and Their Implications, April 2014 Volume. 5 Issue. 2, http://www.ijonte.org, diunduh 2812-2020.

Esim, et al, Clinical Supervision Model to Improve Supervisory Skills of Cooperating, 2013.

Glickman, Carl D., Stephen P. Gordon \& Jo-vita M. RoseGordon, Supervision and Instructional Leadership, New York: Pearson, 2010.

Mulyasa E, Standar Kompetensi dan Sertifikasi Guru, Bandung: Remaja Rosda Karya, 2008), 26.

, Menjadi Kepala Sekolah Profesional, Bandung: PT Remaja Rosdakarya, 2007.

Suryobroto B, Manajemen Pendidikan di Sekolah, Jakarta: PT Rineka Cipta, 2010.

Teachers and University Supervisors during Teaching Practice.H.

U. Journal of Educa- tion Özel Sayý (1), 191-203.

Undang-Undang Republik Indonesia Nomor 14 Tahun 2005 Tentang Guru dan Dosen.

https://www.researchgate.net 